\title{
The Enforceability of Patent Settlement Agreements After Lear, Inc. v. Adkins
}

In many areas of the legal system, parties are encouraged to settle their disputes without resorting to full-dress litigation. ${ }^{1}$ Such compromises conserve judicial resources and provide faster, cheaper, and therefore more effective relief. ${ }^{2}$ To facilitate compromise, courts ordinarily treat settlement agreements as binding and enforceable contracts. ${ }^{3}$ In patent disputes, however, the effect of settlement agreements is problematical. Lower federal courts, faced with three Supreme Court decisions ${ }^{4}$ that are relevant but not dispositive, have created a conflicting body of law, under which settlement agreements are sometimes not enforced at all, ${ }^{5}$ sometimes enforced in part, ${ }^{6}$ and sometimes given almost full effect. ${ }^{7}$

This comment does not seek to resolve or to reconcile the large patent and antitrust issues of which patent settlements are only a part. The Supreme Court's decisions in this area have been the subject of extensive academic interpretation and criticism. ${ }^{8}$ In-

1 E.g., claims to land, Hennessy v. Bacon, 137 U.S. 78 (1890); disputes involving construction contracts, D.H. Overmeyer Co. v. Loflin, 440 F.2d 1213 (5th Cir.), cert. denied, 404 U.S. 851 (1971); personal injury claims, Autera v. Robinson, 419 F.2d 1197 (D.C. Cir. 1969); and contracts for the sale of goods, J. Kahn \& Co. v. Clark, 178 F.2d 111 (5th Cir. 1949).

2 Autera v. Robinson, 419 F.2d 1197, 1199 (D.C. Cir. 1969).

3 That is, questions of the existence of a contract, the meaning of its terms, and special defenses of fraud, duress, or mutual mistake can be raised. Absent these questions, "an agreement of the parties settling a disputed liability is as conclusive of their rights as a judgment would be if it had been litigated instead of compromised." J. Kahn \& Co. v. Clark, 178 F.2d 111, 114 (5th Cir. 1949); accord, Autera v. Robinson, 419 F.2d 1197, 1201 n.17 (D.C. Cir. 1969); Crisp County v. S.J. Groves \& Sons, Co., 73 F.2d 327, 329 (5th Cir. 1934). See generally 6 A. Corbin, Corbin on Contracts § 1268, at $72-73$ (rev. ed. 1962); id. § 1292, at $\mathbf{1 7 8 - 8 0 .}$

- Aronson v. Quick Point Pencil Co., 440 U.S. 257 (1979); Blonder-Tongue Laboratories v. University of $\mathrm{Ml}$. Foundation, 402 U.S. 313 (1971); Lear, Inc. v. Adkins, 395 U.S. 653 (1969). See Part I infra.

- See text and notes at notes $45-48$ infra.

- See text and notes at notes 53-63 infra.

7 See text and notes at notes 68-78 infra.

- A sampling of the articles that discuss Lear, Inc. v. Adkins includes: Arnold \& Goldstein, Life Under Lear, 48 TEx. L. REv. 1235 (1970); Dodds, After Lear v. Adkins-What?, 51 J. PAT. OrF. Soc'y 621 (1969); Jennings \& Bryan, The Ever Expansive Scope of Lear v. Adkins: Does It Have Limits?, 59 J. Pat. Orp. Soc'y 679 (1977); McCarthy, "Unmuzzling" the Patent Licensee: Chaos in the Wake of Lear v. Adkins, 45 Gro. WASH. L. Rev. 429 
stead, the comment argues that patent settlement agreements should be enforced, by their terms, because per se enforceability is the simplest and most practical way of alleviating the current confusion-confusion that benefits neither patentees, licensees, nor the general public.

\section{Supreme Court Decisions}

A patent is "a grant . . . for the term of seventeen years, . . . of the right to exclude others from making, using, or selling [an] invention throughout the United States." ${ }^{\text {T }}$ To ensure that the patent system serves its constitutionally mandated ${ }^{10}$ purpose of stimulating and protecting true invention, and does not provide monopoly returns for ideas that were already part of the public domain or for inconsequential improvements of them, a patentable idea must meet specific criteria of usefulness, novelty, and nonobviousness. ${ }^{11}$

The value of a patent lies in the patentee's ability to enforce his chosen method of exploiting his invention by bringing infringement suits against anyone who makes, uses, or sells it without his consent. ${ }^{12}$ The defenses available to an alleged infringer are noninfringement, patent invalidity, and patent misuse. ${ }^{13}$ The infringer can also take the offensive by bringing a declaratory judgment action $^{14}$ or an antitrust suit. ${ }^{16}$ In all litigation, the patent is accorded

(1977); Stern, Antitrust Implications of Lear v. Adkins, 52 J. PAr. Orf. Soc'y 213 (1970). On Blonder-Tongue, see, e.g., Halpern, Blonder-Tongue: $A$ Discussion and Analysis (pts. 1-2), 53 J. Pat. Orf. Soc'y 761 (1971), 54 J. Pat. Ofr. Soc'y 5 (1972); Kahn, Blonder-Tongue and the Shape of Future Patent Litigation, 53 J. PAT. Orp. Soc'y 581 (1971). Kewanee Oil Co. v. Bicron Corp., 416 U.S. 470 (1974), is discussed in, e.g., Goldstein, Kewanee Oil Co. v. Bicron Corp.: Notes on a Closing Circle, 1974 Sup. Cr. Rev. 81; Stern, A Reexamination of Preemption of State Trade Secret Law After Kewanee, 42 Gro. WASH. L. Rzv. 927 (1974). On Aronson, see, e.g., Altman, A Quick Point Regarding Perpetual Trade Secret Royalty Liability, 61 J. PAT. OFr. Soc'y 510 (1979).

- 35 U.S.C. $\$ 154$ (1976).

${ }^{10}$ U.S. Const. art. I, $\S 8$, cl. 8.

2135 U.S.C. $\$ \S 101-103$ (1976).

12 Id. $\$ \S 271,281$.

13 Noninfringement and invalidity are statutory defenses. Id. \$282(2). Patent misuse is a judicially created defense, analogous to the equitable doctrine of unclean hands. Courts have long held that any attempt by a patentee to expand the scope or duration of the limited monopoly constitutes misuse and renders the patent unenforceable, at least for the duration of the misuse. See, e.g., Brulotte v. Thys Co., 379 U.S. 29 (1964); United States v. Masonite Corp., 316 U.S. 265 (1942); Morton Salt Co. v. G.S. Suppiger Co., 314 U.S. 488 (1942).

1428 U.S.C. $\$ \S 2201-2202$ (1976).

${ }^{15}$ See generally Kennedy, Patent and Antitrust Policy: The Search for a Unitary Theory, 35 Geo. WaSH. L. REv. 512 (1967) (discussion of when and what kinds of patent 
a presumption of validity, and the burden of proving invalidity rests on the party asserting it..18

Three Supreme Court decisions have shaped the treatment of patent settlement agreements within the confines of the statutory scheme just described. None has dealt directly with patent settlements.

\section{A. Lear and Licensee Estoppel}

For over a century, ${ }^{17}$ the doctrine of licensee estoppel generally prevented a patent licensee from challenging the validity of a patent, ${ }^{18}$ even if the license terms did not bar challenges, on the ground that he "should not be permitted to enjoy the benefit afforded by the agreement while simultaneously urging that the patent which forms the basis of the agreement is void."19 In Lear, Inc. $v$. Adkins, ${ }^{20}$ the Supreme Court reconsidered the doctrine of licensee estoppel in light of its recent opinions stressing the public interest in free competition, ${ }^{21}$ and abandoned it. ${ }^{22}$ The Court also set aside a license term that would have required the licensee to pay royalties until the patent was finally declared invalid. ${ }^{23}$ It did not decide, however, whether state contract law or federal patent law would govern with regard to royalties paid before the patent was

misuse amounts to antitrust violation).

16 35 U.S.C. § 282 (1976).

${ }_{17}$ See, e.g., Automatic Radio Mfg. Co. v. Hazeltine Research, Inc., 339 U.S. 827 (1950); Kinsman v. Parkhurst, 59 U.S. (18 How.) 289 (1856). Justice Harlan's treatment of the state of the law before Lear, Inc. v. Adkins, 395 U.S. 653, 663-68 (1969), is somewhat revisionist.

10 A challenge could be made where there was patent misuse or where the license agreement was contrary to public policy. Automatic Radio Mfg. Co. v. Hazeltine Research, Inc., 339 U.S. 827, 836 (1950).

19 Adkins v. Lear, Inc., 67 Cal. 2d 882, 891, 435 P.2d 321, 325-26, 64 Cal. Rptr. 545, 550 (1967), vacated, 395 U.S. 653 (1969).

20395 U.S. 653 (1969). While he was a Lear employee, Adkins applied for a patent on his improvements of gyroscope technology. He then negotiated an agreement with Lear that Lear would pay royalties for the use of Adkins's invention. The agreement gave Lear the right to terminate if no patent issued or if a patent was granted but subsequently held invalid. For several years Lear paid royalties; after 1957 it became convinced that no patent would ever issue and ceased making all but a small number of payments. In 1960 Adkins obtained his patent, and brought suit for the unpaid royalties and for royalties for the entire patent term, arguing that Lear's contractual agreement estopped it to challenge the validity of Adkins's patent.

11 Sears, Roebuck \& Co. v. Stiffel Co., 376 U.S. 225 (1964); Compco Corp. v. Day-Brite Lighting, Inc., 376 U.S. 234 (1964).

32395 U.S. at 668,671 . On this point the Court was unanimous.

2s Id. at 671-74 (although Justice White, concurring in part, argued that this issue was not properly before the Court, id. at $682 \&$ n.2). 
granted. ${ }^{24}$ One of the Court's major premises was that "[1]icensees may often be the only individuals with enough economic incentive to challenge the patentability of an inventor's discovery. If they are muzzled, the public may continually be required to pay tribute to would-be monopolists without need or justification."25

\section{B. Aronson and the Reach of Lear}

In Aronson v. Quick Point Pencil Co., ${ }^{26}$ the designer of a key ring had contracted with a manufacturer to produce it. The contract called for one level of royalty payments while the patent application was pending and a lower level if the application was denied. Dealing only with the second part of the contract, ${ }^{27}$ the Court enforced its terms. "[N]either the holding nor the rationale of Lear controls when no patent has issued, and no ideas have been withdrawn from public use."28 The Court also reiterated its holding in Kewanee Oil Co. v. Bicron Corp. ${ }^{29}$ that federal patent law did not oust state trade secret law, even where the secret was an inherently patentable idea for which no patent protection was sought. ${ }^{30}$ The Court thus limited the reach of Lear: it does not affect the availability of trade secret protection, and it does not apply to contractual arrangements where no patent ultimately issues. The precise question left open in Lear-namely, the enforceability of contracts made during the pendency of a patent application-remains unanswered. ${ }^{\mathbf{s 1}}$

\section{Blonder-Tongue and Incentives to Litigate}

The third decision in the trilogy, Blonder-Tongue Laboratories $v$. University of Illinois Foundation, ${ }^{32}$ wrought a fundamental

24 Id. at 674-75 (with Justice Black, joined by Chief Justice Warren and Justice Douglas, dissenting on this point, id. at 676-77).

2s Id. at 670 .

26440 U.S. 257 (1979).

${ }^{27}$ Quick Point Pencil had paid royalties at the higher rate for 5 years, and at the lower rate for 14. Thereafter it sought a declaratory judgment that the contract was unenforceable. Id. at 259-60.

${ }^{28} \mathrm{Id}$. at 264 .

29416 U.S. 470 (1974).

so Id. at 489-91; see Aronson v. Quick Point Pencil Co., 440 U.S. 257, 262, 265-66 (1979).

s1 Because Quick Point Pencil's challenge dealt only with the later aspect of the contract, "[t]his case does not require us to draw the line between what constitutes abuse of a pending application and what does not." 440 U.S. at 265.

32402 U.S. 313 (1971). 
change in the patentee's ability to protect his patent by litigation. Concerned with the expense of patent litigation and the concomitant drain on judicial resources, ${ }^{33}$ the Supreme Court abandoned

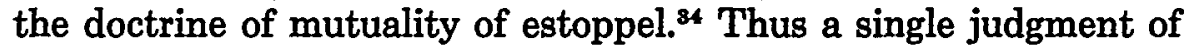
patent invalidity would be conclusive against the patentee, but a judgment of patent validity would not insulate him from further challenges.

\section{Summary}

Together, these three decisions focus attention on patent settlements. Under the Aronson-Kewanee line, the inventor who is willing to settle for trade secret protection, and the would-be patentholder whose application is denied, are both remitted to state law. But relations between the successful patent applicant and his licensee are subject to Lear and Blonder-Tongue. The patentee, if he cannot forestall initial challenges under Lear and is forced to litigate repeatedly under Blonder-Tongue, will seek some alternate method of resolving disputes. The licensee, on the other hand, has his ability to challenge patent validity protected by Lear, but his incentives to challenge are reduced by the prospect of a free ride on someone else's judgment of invalidity under Blonder-Tongue. He, too, may want to settle patent disputes, though his desire may be more to control the timing of a final decision than to end the dispute completely.

\section{Approaches to Settlement Agreements After Lear}

A. Distinguishing Settlement Agreements from Initial Licenses and Consent Decrees

Since the decision in Lear, lower courts have been attempting to determine the proper effect of the Lear Court's sweeping encouragement of challenges to patent validity. Two areas of general agreement have emerged.

In the context of license agreements the Lear principle has not been limited. Under Lear, a licensee remains free to challenge the validity of a patent, no matter what contrary terms the parties include in the license agreement. ${ }^{35}$ Nor can he be forced to treat the

.2s Id. at 334-42.

st Id. at 350.

2s See text and notes at notes 17-25 supra. 


\section{license as binding pending the disposition of his challenge. ${ }^{36}$}

After some initial confusion over whether Lear would abrogate the res judicata effect of consent decrees, ${ }^{37}$ courts generally have adhered to the treatment of such decrees that was standard before Lear. ${ }^{38}$ Thus, although consent decrees reflect the parties' desire to terminate litigation, they are considered adjudications by the courts that enter them ${ }^{39}$ and are given res judicata effect. ${ }^{40}$ The reason commonly adduced is that consent decrees formally are judgments and cannot be ignored without undermining the dignity

so Under Lear, the licensee could not be required to continue royalty payments while his suit was pending, 395 U.S. at 673 , although a finding of patent validity would leave him exposed to damages for infringement. Some courts have required the licensee to continue royalty payments directly to the patentee. Warner-Jenkinson Co. v. Allied Chem. Corp., 567 F.2d 184, 188 (2d Cir. 1977); Nebraska Eng'r Corp. v. Shivvers, 557 F.2d 1257, 1259-60 (8th Cir. 1977). Others have permitted payment into escrow. Precision Shooting Equip., Inc. v. Allen, Inc., 492 F. Supp. 79 (C.D. Ill. 1980), aff'd, 528 Patent, Trademark \& Copyright J. (BNA) A-1 (7th Cir. Apr. 7, 1981). Courts also have held that, at least in the absence of explicit contractual provisions for termination, a licensee challenge does not constitute a material breach of the license that entitles the patentee to cancel and sue for infringement. These courts reason that the threat of termination might discourage licensee challenges, contrary to the policy of Lear. Crane Co. v. Aeroquip Corp., 366 F. Supp. 733, 737-39 (N.D. IIl. 1973), aff'd in relevant part, 504 F.2d 1086 (7th Cir. 1974); accord, Skill Corp. v. Lucerne Products, Inc., 206 U.S.P.Q. (BNA) 792, 823-24 (N.D. Ohio 1980); Lee v. Lee Custom Eng'r, Inc., 476 F. Supp. 361 (E.D. Wis. 1979).

s7 Compare Business Forms Finishing Serv., Inc. v. Carson, 452 F.2d 70, 73-75 (7th Cir. 1971) (refusing enforcement of consent decree of validity primariiy on policy basis) with Maxon Premix Burner Co. v. Eclipse Fuel Eng'r Co., 471 F.2d 308, 311-12 (7th Cir. 1972) (avoiding issues of consent decree's res judicata effect, and holding that defendant had effectively waived the right to challenge by failing to raise validity claim until after losing on infringement claim at trial), cert. denied, 410 U.S. 929 (1973). See also Arnold \& Goldstein, supra note 8, at 1246 (expressing concern that under Lear consent decrees would not be conclusive).

s8 American Equip. Corp. v. Wikomi Mfg. Co., 630 F.2d 544 (7th Cir. 1980); Wallace Clark \& Co. v. Acheson Indus., Inc., 532 F.2d 846 (2d Cir.), cert. denied, 425 U.S. 976 (1976); Schlegel Mfg. Co. v. USM Corp., 525 F.2d 775 (6th Cir. 1975), cert. denied, 425 U.S. 912 (1976); Broadview Chem. Corp. v. Loctite Corp., 474 F.2d 1391 (2d Cir. 1973); Schnitger v. Canoga Elecs. Corp., 462 F.2d 628 (9th Gir. 1972) (per curiam); Swift Chem. Co. v. Usamex Fertilizers, Inc., 490 F. Supp. 1343 (E.D. La. 1980).

In cases in which a consent decree is not given res judicata effect, the result usually turns on failure to meet the Addressograph requirement, discussed in text and notes at notes 42-43 infra. See, e.g., Kaspar Wire Works, Inc. v. Leco Eng'r \& Mach., Inc., 575 F.2d 530 (5th Cir. 1978) (no recital of infringement); Kraly v. National Distillers \& Chem. Corp., 502 F.2d 1366 (7th Cir. 1974) ( $\$ 8,000$ payment by licensee inadequate basis from which to infer infringement). But see American Equip. Corp. v. Wikomi Mfg. Co., 630 F.2d 544, 547 n.3 (7th Cir. 1980).

s9 United States v. Swift \& Co., 286 U.S. 106, 115 (1932) (a consent decree is "a judicial act, not a contract").

40 1B J. Moore, Federal Practice ๆ 0.409[5], at 1032 (2d ed. 1980). 
and authority of the courts and threatening res judicata principles. ${ }^{11}$

The res judicata effect of patent consent decrees is subject to one important qualification, first stated thirty-five years ago in $A d$ dressograph-Multigraph Corp. $v$. Cooper. ${ }^{42}$ A consent decree of patent validity will be given res judicata effect only if it contains "either an adjudication of infringement or a grant of some relief from which infringement may be inferred."4s No additional limitations on the effect of consent decrees have arisen in response to the Supreme Court's decision in Lear. ${ }^{44}$

Res judicata principles are not strictly applicable in the context of settlement agreements, because such agreements are not necessarily accompanied by a dismissal with prejudice. Yet these agreements do share some of the characteristics of a consent decree in that they bring an early end to costly litigation, and they are not clearly within the realm of ordinary contract law preempted by Lear. As a result, courts still are faced with a choice between the traditional encouragement of settlements and a patent exception of uncertain dimensions. No consistent approach is discernible. The

41 See generally Note, "To Bind or Not to Bind": Bar and Merger Treatment of Consent Decrees in Patent Infringement Litigation, 74 CoLvM. L. REv. 1322 (1974).

12156 F.2d 483 (2d Cir. 1946). See also 1B J. Moors, supra note 40, 1 0.405[11], at 786.

$15156 \mathrm{~F} .2 \mathrm{~d}$ at 485 . The rationale for the Addressograph requirement is that patent invalidity is a second-line defense for the defendant in an infringement suit. His first effort will be to show noninfringement; if he can make such a showing, the patent is no real threat to him, whether it is valid or invalid. Under these circumstances, "the validity of a patent may be too readily conceded by a party not found to have infringed it." Wallace Clark \& Co. v. Acheson Indus., Inc., 532 F.2d 846, 848 (2d Cir.), cert. denied, 425 U.S. 976 (1976).

34 That result seems proper, both for the traditional reasons, see text and note at note 41 supra, and because the impact of consent decrees on Lear policies is minimal. Consent decrees inherently have only the limited res judicata effect of merger and bar, or claim preclusion. See Note, supra note 41, at 1343. Because no issue is "actually litigated," collateral estoppel or issue preclusion is impossible. (It is mistaken to equate the Addressograph requirement with the "necessary and sufficient holding" requirement of collateral estoppel, as is done in Comment, Res Judicata Effect of Consent Judgments in Patent Litigation, 18 B.C. InDus. \& CoM. L. REv. 66 (1976).) The parties to a consent decree therefore can bring new suits whenever there is a new cause of action, and strangers can make no use whatsoever of the judgment.

The Addressograph requirement is simply a means of guaranteeing that the process of determining which claims are to be merged or barred retains a certain integrity. It provides only a rough test, however: a recital of infringement does not automatically suggest that the issue of patent validity was hard-fought, because infringement liability can also be sham. Whatever doubts there are about the propriety of a particular consent decree, or about the scope of the cause of action, should be resolved by the judge who enters the consent decree rather than by the judge who is asked to give it res judicata effect in a later proceeding. See, e.g., American Equip. Corp. v. Wikomi Mfg. Co., 630 F.2d 544 (7th Cir. 1980) (error to refuse res judicata effect to a consent decree, based on later court's scrutiny of docket sheet and affidavits in original proceeding), rev'g 202 U.S.P.Q. (BNA) 17 (S.D. III. 1978). 
decided cases tend to stitch together rhetorical commonplaces rather than to advance legal arguments, and the outcome sometimes depends on a technical ground that either minimizes the dilemma or ignores it altogether.

\section{B. Various Approaches to Settlement Issues}

1. Applying Lear. Massillon-Cleveland-Akron Sign Co. v. Golden State Advertising Co. ${ }^{45}$ was one of the first settlement cases decided after Lear. At issue was the enforceability of a nocontest clause in a settlement entered into to avert threatened legal action. The Ninth Circuit treated the clause as "void on its face and unenforceable,"46 finding that "the recognized policy favoring settlement of disputes . . . must give way to the policy favoring free competition in ideas not meriting patent protection."17 The court saw no point in distinguishing between initial licenses and settlements, noting that such a distinction would simply invite parties to couch licenses as settlements in order to avoid Lear. ${ }^{48}$

The court might have pointed to several more specific factors in order to justify nonenforcement of the particular settlement agreement. First, it compromised threatened, not actual, litigation, ${ }^{49}$ making it impossible for anyone but the parties themselves to know whether there was in fact any compromise. Second, the settlement agreement itself was suspicious: the infringer promised to cease his allegedly infringing activities, forego all challenges to patent validity, and pay $\$ 500$ in liquidated damages. ${ }^{50}$ Thus, despite its broad language, the Golden State court may have been worried about a sham settlement. The possibility that shams could be dealt with by a method less drastic than the one the court chose was not discussed in the case.

2. Using Characterization Techniques to Avoid Lear. In Lear, the Supreme Court left open whether Lear had to pay all royalties accrued between the negotiation of the license agreement and the institution of the lawsuit in which Lear's defense was its claim of patent invalidity. ${ }^{51}$ In Aronson, the issue remained un-

ts 444 F.2d 425 (9th Cir.), cert. denied, 404 U.S. 873 (1971).

to Id. at 427 . 1976).

47 Id.; accord, Sidewinder Marine, Inc. v. Nescher, 404 F. Supp. 680, 683-84 (N.D. Cal.

4844 F.2d at 427 .

49 Id. at 425 .

so Id.

si See text and note at note 23 supra. 
resolved, because the respondent had paid all royalties up to the filing of a declaratory judgment action. ${ }^{\mathbf{5 2}}$ In the settlement context, courts have allowed parties to make use of the possible limitation on Lear to give partial effect to settlement agreements.

Ransburg Electro-Coating Corp. v. Spiller \& Spiller, Inc. ${ }^{\mathrm{k}}$ illustrates this approach. There the patentee and a user of a device alleged to infringe the patent had entered into a settlement calling for the infringer to pay $\$ 70,000$ over five years as "compensation" for past infringement. ${ }^{54}$ In a separate document, dated two weeks later, ${ }^{\text {ss }}$ the patentee licensed the infringer to use the patented device in the future under the patentee's "customary terms and conditions." all payments, and the patentee sued for enforcement of the $\$ 70,000$ portion of the agreement. The district court treated the separate documents as one patent license agreement, ${ }^{88}$ and held it unenforceable under Lear and Golden State. ${ }^{59}$ The Seventh Circuit reversed, treating the part of the agreement sued on as a binding agreement to pay damages for past infringement, given in consideration for the good-faith compromise of a bona fide claim. ${ }^{60}$ Thus construed, the transaction lay outside the scope of Lear and within the policy of favoring "the expedient and orderly settlement of disputes and the fostering of judicial economy."61

The Seventh Circuit may not have distorted the Ransburg transaction in order to avoid Lear problems, but the danger of exalting form over substance that inheres in the Ransburg approach is well illustrated in a Second Circuit decision. In International Telemeter Corp. $v$. Teleprompter Corp. ${ }^{62}$ the court enforced an agreement that provided for $\$ 245,000$, payable in installments, and a five-year royalty-free license. The court was willing to character-

s2 See text and notes at notes 27, 31 supra.

ss 489 F.2d 974 (7th Cir. 1973).

st Id. at 976 .

ss Id.

so Ransburg Electro-Coating Corp. v. Spiller \& Spiller, Inc., 340 F. Supp. 1385, 1387 (N.D. Ill. 1972), rev'd, 489 F.2d 974 (7th Cir. 1973).

${ }^{s 7}$ At that time, in proceedings involving the same device and a different alleged infringer, the Fourth Circuit held that Ransburg's patent had not been infringed. Ransburg Electro-Coating Corp. v. Ionic Electrostatic Corp., 395 F.2d 92 (4th Cir. 1968), cert. denied, 393 U.S. 1018 (1969).

ss 340 F. Supp. at 1388.

Id. at 1389.

60 489 F.2d at 977.

-1 Id. at 978.

o2 592 F.2d 49 (2d Cir. 1979). 
ize the payment as "liquidated damages for past infringement and not a royalty payment for future use."63

In addition to separating out enforceable components of settlement agreements, the courts apparently have relied on Lear to guide their interpretation of other settlement contract terms. In Warner-Jenkinson Co. v. Allied Chemical Corp., ${ }^{64}$ the parties to an infringement suit had entered into a settlement license containing a provision that the licensee would not terminate the arrangement for two years. The majority interpreted the provision to bar the licensee from defaulting on royalty payments, but not from bringing a declaratory judgment action within the two-year period. ${ }^{65}$ Judge Timbers maintained in dissent that the clause was most naturally interpreted as a two-year ban on all challenges to patent validity. ${ }^{68}$ In what was obviously a close case, Lear tipped the balance for the majority: "[I]f a settlement agreement contains an explicit prohibition on licensee suits during some future period, . . . a court may feel that effect should be given to such provisions. However, the Lear decision militates against reading such provisions into a settlement agreement." 67

3. Defining away Lear. The most enthusiastic support for the enforceability of patent settlements has come from the Sixth Circuit. Aro Corp. v. Allied Witan Co. ${ }^{88}$ involved a license agreement entered into to compromise litigation. When the first royalty payment fell due, the licensee refused to pay; in the patentee's subsequent suit for specific performance of the license agreement, the licensee argued that under Lear he should have the opportunity to demonstrate patent invalidity and consequently failure of consideration for the settlement agreement. The Sixth Circuit upheld an order for specific performance.

65 Id. at 57.

at 567 F.2d 184 (2d Cir. 1977).

es Id. at 188.

68 Id. at 189 (Timbers, J., dissenting).

62 567 F.2d at 188. But see the same case on remand, 477 F. Supp. 371 (S.D.N.Y. 1979): "[A] specific provision that plaintiffs shall not commence another litigation in less than two years . . . may present a question of its enforceability in the light of Lear, Inc. v. Adkins." Id. at 399 (Weinfeld, J.) (dictum) (footnote omitted).

531 F.2d 1368 (6th Cir.), cert. denied, 429 U.S. 862 (1976). Chief Judge Markey of the U.S. Court of Customs and Patent Appeals was sitting by designation and wrote the opinion for the unanimous panel. It is worth noting that the Court of Customs and Patent Appeals and the Supreme Court have differed over other aspects of patent policy. See, e.g., Parker v. Flook, 437 U.S. 584 (1978), rev'g In re Flook, 559 F.2d 21 (C.C.P.A. 1977) (patentability of algorithm); Brenner v. Manson, 383 U.S. 519 (1966), rev'g In re Manson, 333 F.2d 234 (C.C.P.A. 1964) (the utility requirement for process patents). 
The arguments marshalled in support of the result are curious. For example, the opinion asserts that settlement is "of particular value in patent litigation," because patent litigation is so time-consuming and complex..$^{69}$ But Lear had assumed that litigation was a necessary corrective in the patent system, ${ }^{70}$ and Blonder-Tongue had proposed to limit the undesirable features of patent suits by dispensing with repetitious litigation rather than by abbreviating individual lawsuits. ${ }^{71}$ Lear, Judge Markey argued, did not "condone a kind of gamesmanship, wherein an alleged infringer, after employing the judicial system for months of discovery, negotiation and sparring, abandons its challenge to validity, executes a license in settlement, and then repudiates the license and seeks to start the fight all over again in the courts."72 If the focus is on misuse of judicial resources, Lear did not condone, or even consider, the strategy. If the focus is on gamesmanship between the licensee and the patentee, Lear inevitably allowed it, because it permitted the licensee to challenge no matter what the license terms were or how long the licensee had acquiesced in them. Judge Markey's claim that Lear's anticompetitive concerns were not implicated because the patent in Aro exerted little, if any, monopoly power ${ }^{73}$ makes a distinction where Lear drew none. Lear's premise was that any invalid patent has the potential to earn undeserved monopoly returns, and that a licensing agreement under an invalid patent makes the potential abuse actual. The Aro court's premise is that only patents whose commercial value is above a certain unspecified minimum are worth bothering about. ${ }^{74}$ Finally, the Sixth Circuit argued that not letting Allied Witan or its privies contest validity would not seriously inhibit challenges, because other licensees were available to take up the standard. ${ }^{75}$ Again, the distinction is not one Lear makes: any licensee under Lear can challenge any patent at any time during the existence of the license.

Having decided the case before it, the Sixth Circuit then proposed a balancing test, to determine when settlements would be conclusive and when a settling party would be permitted to chal-

69 531 F.2d at 1372.

70395 U.S. at $670-71$.

72402 U.S. at 348-50.

$72531 \mathrm{~F} .2 \mathrm{~d}$ at 1373.

7s Id. at 1373-74. The royalty payments for the full term of the license, $3 \frac{1 / 2}{2}$ years, were $\$ 1,668$. Id.

"See note 73 supra and the court's reference to "monopolophobia," $531 \mathrm{~F} .2 \mathrm{~d}$ at 1374.

${ }^{76}$ Id. at 1374 . 
lenge, notwithstanding the settlement. The courts should rely on "[e]vidence, not monopolophobia." They should require the party who seeks to avoid the consequences of a settlement agreement to show that the patent "does in fact have the effect of a 'tax on the public,' is in fact a cause of increased pricing, is in fact serving to limit competition in its product line or does in fact exert substantial effect upon the public," and that "the proffered challenge is the only one likely to be made."77 Again, Judge Markey did not explain why Lear allows such balancing in the settlement context but denies it for licenses. The Second Circuit's characterization of the Aro test as "imprecise and uncertain"78. is understated. It is not clear how a party could show any of the conditions the test requires, or how a court could evaluate the showing. Indeed, putting this burden on the party who seeks to treat the settlement as unenforceable may be tantamount to enforcing patent settlements. If so, the test is disingenuous.

\section{A Rule of Per Se Enforceability}

Judge Markey's attempt to narrow the scope of Lear in the context of patent settlements follows the efforts of many others, ${ }^{79}$ including the Supreme Court itself, ${ }^{80}$ to confine Lear elsewhere. Although it is difficult to put forward theoretical arguments for the enforcement of patent settlement agreements that do not apply with nearly equal force to patent licensing agreements, there are several practical reasons for establishing a clear rule enforcing patent settlement agreements, uncomplicated by the balancing that Judge Markey proposed in Aro.

As has been observed, a patent rewards inventors for their ideas only to the extent that they can enforce it. ${ }^{81}$ The more frequently they must go to the courts to enforce their patents, the less valuable the patents are. Furthermore, it is far from clear that

Id.

77 Id.

${ }^{78}$ Warner-Jenkinson Co. v. Allied Chem. Corp., 567 F.2d 184, 188 (2d Cir. 1977). Judge Timbers, dissenting, thought the test was "a sound accommodation of the competing interests ... involved." Id. at 190.

${ }^{79}$ E.g., Ransburg Electro-Coating Corp. v. Spiller \& Spiller, Inc., 489 F.2d 974, 977-78 (7th Cir. 1973) (Lear does not reach damages for past infringement); Troxel Mfg. Co. v. Schwinn Bicycle Co., 465 F.2d 1253 (6th Cir. 1972) (rejecting rule that would allow successful licensee challengers to recover back royalties).

so Aronson v. Quick Point Pencil Co., 440 U.S. 257 (1979); Kewanee Oil Co. v. Bicron Corp., 416 U.S. 470 (1974); see text and notes at notes 26-31 supra.

s1 See text and notes at notes 9-16 supra. 
patent litigation effectively distinguishes inventions that are patentable from those that are not. ${ }^{\mathbf{2 2}}$ Even assuming, however, that some litigation is desirable, more litigation is not necessarily more desirable. Forcing patentholders to litigate every dispute fully or risk litigating again may tax judicial resources without correspondingly reducing the number of invalid patents. If settlements were not allowed as a means of resolving disputes, the only alternative to full-dress litigation would be consent decrees. ${ }^{83}$ But their effect depends on how the court reviewing the case interprets the $A d$ dressograph requirements. ${ }^{84}$ Moreover, the very availability of a consent decree may turn largely upon the temperament of the granting judge. On the one hand, a consent decree may be no more than an exercise in rubber stamping, subjected only to "perfunctory inspection accompanied by a hosanna because another case is off the calendar."'8s On the other hand, one court has stated that in deference to Lear it has "consistently . . . refused to sign consent decrees or judgments in patent cases containing a finding that the patent involved was valid or that it had been infringed by the defendant.",86

Given the limits imposed on Lear in other contexts, the burdens a no-settlement rule would place on judicial resources, and the uncertain availability of consent decrees, Lear should not be

22 There are two distinct problems here. One is how to allocate responsibility between the Patent Office and the courts. Remarking on the "notorious difference between the standards applied by the Patent Office and by the courts," the Supreme Court thought that "the primary responsibility for sifting out unpatentable material lies in the Patent Office. To await litigation is-for all practical purposes-to debilitate the patent system." Graham v. John Deere Co., 383 U.S. 1, 18 (1966).

The second difficulty is that statistics about patent litigation are unreliable as a basis for judging its effectiveness. G. Koenig, PATBNT Invarmity: A Statistical and Substantive ANALysis 1-4, 4-31 to -32 \& Table 17 (1976), indicates that $60-65 \%$ of adjudicated patents are found invalid, but that this figure represents only about $0.1 \%$ of the Patent Office's output on an average annual basis. Markey, The Status of the U.S. Patent System-Sans Myth, Sans Fiction, 59 J. PAT. Orf. Soc'y 164, 167 (1977), points out that the ratio of adjudicated patents to patents subject to adjudication is so small as to make conclusions unreliable.

ss This result is foreshadowed in the District Court's opinion on the remand of WarnerJenkinson, where the judge reprimanded both parties for not having originally entered a consent decree or obtained a judgment with full res judicata effect. "While settlement of actions is to be encouraged, those which are but a temporary truce in the parties' continued warfare and present only the facade but not the reality of settlement should not be encouraged." 477 F. Supp. 371, 400 (S.D.N.Y. 1979).

See text and notes at notes 38, 44 supra.

s5 Kaspar Wire Works, Inc. v. Leco Eng'r Mach., Inc., 575 F.2d 530, 538 (5th Cir. 1978).

${ }^{86}$ Butterfield v. Oculus Contact Lens Co., 332 F. Supp. 750, 760 (N.D. III. 1971). 
fully extended to patent settlement agreements. This conclusion corresponds with the decisions of several lower federal courts that have, in effect, marked off settlement agreements from the broad sweep of the Lear doctrine, but these courts have not offered rules that provide sufficient predictability. The decisions of WarnerJenkinson and International Telemeter within the same circuit illustrate the problems with the current ad hoc approach. Even worse, the balancing test Judge Markey proposed in Aro-if it is taken seriously-injects into every settlement case a whole set of quasi-antitrust issues. It would be better to treat settlements as per se enforceable, and achieve a modicum of consistency, leaving to the Supreme Court or Congress ${ }^{87}$ the ultimate determination of how far-reaching the Lear assumptions should be.

One qualification to a rule of per se enforceability is necessitated by the concern expressed in Golden State for the ease with which Lear can be circumvented by licenses masquerading as settlements. A rule that makes enforceable only settlements entered into to compromise actual, as opposed to threatened, litigation would exclude agreements like the one in Golden State.$^{88}$ Although a line drawn at the commencement of litigation necessarily is somewhat arbitrary, it would prevent the most transparent attempts to circumvent Lear, without requiring courts in every case to evaluate the adequacy of consideration in terms of the credibility of threats of legal action or guesses about which party might prevail.

\section{Conclusion}

Although settlement agreements ordinarily are encouraged as a means of resolving legal disputes, the effect of attempting to compromise patent litigation by settlement currently is doubtful. The Supreme Court has adopted a theory of patent law that emphasizes the importance of litigation and the anticompetitive consequences of invalid patents, but it has never explicitly applied that theory to settlement agreements.

87 There is precedent for congressional action in this area. In 1976 a patent law revision bill containing an "anti-Lear" provision was passed by the Senate. S. 2255, 94th Cong., 2d Sess. § 296, 122 CoNG. REc. 4507 (1976). It was never enacted, however. For a history of legislative action, see Scott \& Unkovic, Patent Law Reform: A Legislative Perspective of an Extended Gestation, 16 WM. \& Mary L. Rev. 937 (1975), reprinted in 122 Cong. Rec. 4520 (1976); Whale, Patent Law Revision-A Dark Look at S. 2255, 59 J. Pat. Orf. Soc'y 153, 153 (1977).

${ }^{88}$ See text and notes at notes 45-50 supra. 
As a theoretical matter, if the Supreme Court's premises are correct, perhaps settlement agreements should be discouraged. Or, if its premises are wrong, Lear, Inc. $v$. Adkins and related cases should be reexamined. The focus of this comment has not been on theory, however, but on practical concerns. In the absence of a clear legislative or judicial directive, courts should treat patent settlement agreements, at least where they are entered into after litigation has commenced, as they do other settlement agreements-as binding and enforceable contracts.

Ellen Sudranski Friedman 